Walter Benjamin i metodologia antropologicznego materializmu. Krzesanie dialektycznych iskier na metalowej głowie Ernsta Thälmanna

I w swojej metodologii, i w polityce Walter Benjamin pozostaje wierny zasadzie, by postępować „zawsze radykalnie, nigdy konsekwentnie". Dlatego dla współczesnych badaczy/-ek miasta zainspirowanych jego dziełem największym wyzwaniem jest operacjonalizacja jego materialistycznej metodologii. Materializm antropologiczny Benjamina przekracza granice dyscyplin naukowych, mieszcząc się wedle określenia Theodora Adorna - „na granicy magii i pozytywizmu". Punktem przejścia jednego w drugie jest obraz dialektyczny. Aby dojść do tego punktu, Benjamin przeprowadza serię eksperymentów percepcyjnych i analitycznych, które można potraktować jako swoiste etiudy dialektyczne, „ćwiczenia w patrzeniu”. Artykuł wyodrębnia takie techniki z pism Benjamina, wskazuje na ich filozoficzne podłoże oraz testuje je poprzez badanie wspótczesnego przykładu. Jest nim ogromny berliński pomnik komunisty Ernsta Thälmanna, na zmianę brudzony przez graficiarzy i czyszczony przez lewicowy kolektyw.

Słowa kluczowe: Walter Benjamin, materializm antropologiczny, obraz dialektyczny, miasto, pomnik, pamięć, dialektyka, Ernst Thälmann, mesjanizm 
Pedagogiczny aspekt niniejszego przedsięwzięcia:

"Tkwiace $w$ nas medium obrazotwórcze przyuczyć do stereoskopowego, wielowymiarowego wgladu w cienie historii" Walter Benjamin (cytując Rudolfa Borchardta)

\section{Pozytywizm magiczny}

Rola, jaką Walter Benjamin odgrywa we współczesnych studiach miejskich, jest tyleż szczególna, co na wielu poziomach problematyczna. Jego główne dzieło - Pasaże - jest fascynującym zbiorem cytatów, gotową kwerendą dla współczesnych badaczy, którzy dzięki niemu nie muszą przedzierać się przez dziewiętnastowieczne monografie o konstrukcjach żelaznych. Z drugiej strony często używają oni napisanych przez Benjamina fragmentów w funkcji - o benjaminowska ironio! ornamentu pracy naukowej, zdobiącego niektóre współczesne teksty niczym secesyjne kwiaty na fasadach dziewiętnastowiecznych kamienic. Im bardziej dana dziedzina chce się prezentować jako bliska społecznej, kulturowej czy miejskiej praxis, tym ostrożniejsza jest wobec spekulatywnego charakteru filozofii Benjamina, pozostawiając z niej tylko „ładny cytat”, a skupiając się na historyzującej systematyce. Niezwykle systematyczne i solidne, rozprawy rekonstruujące historyczną figurę flaneura albo odtwarzające zawartość i układ dziewiętnastowiecznych wystaw często moszczą Benjaminowi miejsce w dziedzinie znienawidzonej przez niego „naukowej przytulności” ${ }^{1}$, od której metoda dialektyczna miała być ucieczką.

Istoty tego problemu można szukać już w samej formie Pasaży, które są jednocześnie dziełem fragmentarycznym i całościowym. Z eklektycznego zbioru cytatów, z którego tak łatwo jest wyrwać coś na potrzeby własnego toku myśli, wyłania się pełen pęknięć i pustych miejsc, ale jednak spójny system filozoficzny. Materializm Benjamina obejmuje zarówno ontologię, jak i epistemologię, a wizja teologiczna ściśle powiązana jest z zarysem programu politycznego. Benjamina „dziwny rodzaj materializmu nie wybiera żadnej konkretnej dyscypliny spośród różnorodnych pól zainteresowań (sięgających od estetyki, języka i krytyki literackiej do teologii i polityki); jego materializm formułuje raczej jakieś szczególne podejście, metodologię, z którą podchodzi on do wszystkich

1 W. Benjamin, Pasaże, red. R. Tiedemann, tłum. I. Kania, Kraków 2005, s. $914(\mathrm{O}, 81)$. 
tych pól”2 ${ }^{2}$ Tymczasem znaczna część badaczy i badaczek interpretuje Benjamina wyłącznie w kategoriach własnej dyscypliny, zaś nie radzi sobie z operacjonalizacją jego materialistycznej metodologii. O ile filozofowie-benjaminiści, zajęci subtelnymi konstrukcjami teoretyczno-pojęciowymi, analizując narzędzia poznawcze Benjamina, często nie czują się zobowiązani dawać żadnych praktycznych wskazówek metodologicznych, o tyle teoretycy miasta, obficie czerpiąc z Pasaży, przemilczają mesjanistyczne czy ontologiczne wątki myśli autora. Sztywne metodologie dyscyplin, a także zwykły brak wyobraźni czynią niemożliwym dostęp do „antropologicznego materializmu” Benjamina, który według Adorna sytuuje się „na skrzyżowaniu magii i pozytywizmu”³.

Analizując miejskie wątki dzieła Benjamina, łatwo jest wybrać jedną z dróg - magię lub pozytywizm - trudniej jest wytrwać na skrzyżowaniu. „Przytulnie” jest razem z Benjaminem analizować dziewiętnastowieczny Paryż, dużo niebezpieczniej jest naprawdę zabrać go na ulice naszych miast. Podstawowym problemem tych, którzy chcą Benjamina potraktować zgodnie z jego własną filozofią ${ }^{4}$, jest pytanie, jak - nie będąc Walterem Benjaminem - spojrzeć na dzisiejsze miasta „po benjaminowsku"? Nie znaczy to, że nie powstają samodzielne analizy współczesnych miast inspirowane Pasażami albo miejskimi esejami Benjamina. Niemal za każdym razem są to jednak dzieła oparte na intuicyjnej metodologii i wystawione na wszystkie płynące z tego zarzuty. Wydaje się, że po latach traktując dziwną formę Pasaży jako oczywistą, zbyt rzadko w głębszy sposób zdajemy sobie sprawę, że Pasaże to nie zamknięte dzieło, ale bardzo rzetelny, metodyczny research ${ }^{5}$, który obejmuje zbieranie cytatów i fragmentów z cudzych książek, uważne obserwacje poczynione podczas spacerów po Paryżu oraz momenty iluminacji, w których z metodycznych poszukiwań rodzą się zalążki nowej filozofii i nowej metody antropolo-

2 S. Khatib, Karl Marx, Walter Benjamin and the Spectre of the Messianic: Is There a Materialist Theory of Time?, http://anthropologicalmaterialism.hypotheses. org/844

3 T.W. Adorno, W. Benjamin, Briefwechsel 1928-1940, Frankfurt 1994, s. 368.

4 A zatem wykorzystać dzieło, wciągnąć je w nasze myślenie o rzeczywistości i o przeszłości i potraktować z naszej konkretnej perspektywy historycznej: „Powiada się, że metoda dialektyczna polega na każdorazowym uwzględnianiu konkretnej historycznej sytuacji jej przedmiotu. Ale to nie wystarcza, bo w równej mierze chodzi tu o zadośćuczynienie konkretnej historycznej sytuacji zainteresowania jej przedmiotem" - W. Benjamin, Pasaże, K 2, 3, s. 435.

5 Benjamin lubił podkreślać, że praca nad Pasażami zaczęła się pod sklepieniami Bibliotheque Nathionale co najmniej w tym samym stopniu, co pod sklepieniami pasaży (W. Benjamin, Pasaże, s. 889). 
gicznego, dialektycznego materializmu. Te momenty przeskoku pomiędzy pozytywizmem a magią możemy w Pasażach obserwować in statu nascendi, patrząc, jak Benjamin testuje swoje pomysły, wielokrotnie przepisując je w różnych wersjach i zestawiając na powrót z tym, co zebrał w bibliotece i na ulicy, jak wyciaga to, co „magiczne” (a to znaczy: filozoficzne, teologiczne, polityczne i mesjańskie zarazem) z porządku miejskiej codzienności. Owe dialektyczne punkty zwrotu są kluczowe i dopiero z ich perspektywy możemy zobaczyć poszczególne „techniki patrzenia na miasto”. Wszelkie pozytywistyczne wskazówki Benjamina stają się trywialne bez odniesienia teologicznego, natomiast „magicznośc” wszelkich prób myślenia o mieście à la Benjamin bez pozytywistycznego programu kończy się czystą literackością. Czy da się zatem przyuczyć oko do dialektycznego patrzenia na miasto?

W niniejszym artykule postaram się z miejskich tekstów Benjamina wydobyć kilka konkretnych, operacjonalizowalnych technik dialektycznego spojrzenia, pokazując zarówno ich praktyczny, metodyczny wymiar oraz szerszy kontekst filozoficzny, w jakim Benjamin traktuje miasto jako szczególny obiekt badań. Benjaminowskie „techniki patrzenia” przetestuję w spojrzeniu na niewielki plac na Prenzlauer Berg w Berlinie, na którym stoi ogromny zaniedbany pomnik komunistycznego bohatera Ernsta Thälmanna. Starając się odsłonić jak najwięcej warstw podupadłych fantasmagorii władzy w ich miejskim „życiu po życiu”, chcę jednocześnie pokazać filozoficzno-historyczny wymiar Benjaminowskiej metody. Graeme Gilloch nazywa tę metodę praktyką archeomonadologiczną. Jak podkreśla Susan Buck-Morss, obrazy dialektyczne Benjamina nie są

ani estetyczne, ani arbitralne. [Benjamin] rozumiał swoją ,perspektywę" historyczną jako takie spojrzenie na przeszłość, które czyni teraźniejszość, jako rewolucyjny „czas-teraz”, swoim punktem ogniskowym. Ten punkt był dla Benjamina - i powinien być dla jego interpretatorów - latarnią morską, która wyznacza ich kurs. Bez jej stałego światła ryzykują oni naiwny zachwyt nad błyskotliwością fragmentów pism Benjamina (albo własnych), która w końcu ich oślepi ${ }^{6}$.

\section{Zeit(t)raum czyli snoczasoprzestrzeń}

Miasto interesuje Benjamina przede wszystkim jako materialno-temporalny model rzeczywistości. Słynna metafora z $O$ pojęciu historii nabiera

6 S. Buck-Morss, The Dialectics of Seeing: Walter Benjamin and the Arcades Project, London 1989, s. 339. 
nowego wymiaru, jeśli na miejsce abstrakcyjnej katastrofy, na którą patrzy przerażony anioł historii, podstawimy miasto. Każde miasto jest swoją własną ruinę, zarówno w wymiarze fizycznym, jak i na poziomie utraconych możliwości oraz niezrealizowanych fantazji (w tym sensie najnowszy wieżowiec jest ruiną nie mniej niż podupadający pasaż). Jeżeli wyobrazimy sobie miejskie uniwersum Paryża, mieszczące w sobie wszystkie przeszłe, teraźniejsze i przyszłe zdarzenia, wszystkie przeszłe i obecne miejsca, wszystkich ludzi i ich pragnienia, to takie uniwersum jest właściwym, choć z naszej ziemskiej perspektywy nieosiągalnym celem poznania. Patrząc na jej ruinę, Benjamin zawsze szuka wzrokiem tej całości. W tym sensie technika Benjaminowskiego patrzenia na miasto jest podobna do oglądania autostereogramów: dopiero kiedy próbujemy spojrzeć przez kolorowy obrazek gdzieś w (zakrytą przecież przez niego) dal, on sam staje się trójwymiarowy, a jego właściwy przedmiot wyłania się z kolorowego chaosu punktów - nagle - tuż przed naszymi oczami.

Miasto, jakie widzimy (miasto-ruina) jednocześnie zakrywa i oferuje dostęp do swojej nieskończonej całości. Tak jak fizjonomista z linii mimicznych próbuje wyczytać złożoność ludzkiego charakteru, tak zadaniem dialektyka jest próba dotarcia do zrujnowanej całości poprzez materię, która - jak twarz - potrafi doskonale kłamać, a zarazem ciągle zdradza się poprzez swoją niekontrolowaną mimikę. Pomimo częstych odwołań do fizjonomii miasta, Benjamin nigdy nie popada w prostą antropomorfizację. Komponent antropologiczny uzupełnia Marksa, podkreślając dogłębnie ludzki - jednostkowy i kolektywny - wymiar wszelkiej materii. Przejmując marksowskie kategorie bazy i nadbudowy, Benjamin dodaje im subtelności, podkreślając ekspresyjny charakter tej ostatniej:

jeśli baza w jakiejś mierze określa treści myślenia i doświadczenia na poziomie nadbudowy, a owo determinowanie nie jest zwykłym odbiciem, to jak - abstrahując całkowicie od treści jej genezy - należy ją charakteryzować? Otóż jako wyraz. Nadbudowa jest wyrazem bazy ${ }^{7}$.

Dialektyczny proces pomiędzy bazą a nadbudową ma jeszcze jeden, subtelniejszy poziom, który „rozgrywa się pomiędzy kolektywną wyobraźnią i produkcyjnym potencjałem nowej natury, którą istoty ludzkie powołały do istnienia, ale której nie potrafią jeszcze objąć

7 W. Benjamin, Pasaże, s. 436 (K 2, 5). 


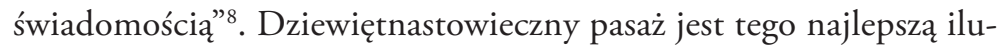
stracją. O ile bowiem z analizy środków i stosunków produkcji oraz towarzyszących im idei można wnioskować o konieczności pojawienia się nowych miejsc handlu, z samej takiej analizy nie wynika jeszcze w żaden sposób specyficzna forma pasażu. Benjamin oprócz przyczyny ekonomicznej widzi w pasażu pewien ekspresyjny (estetyczny) naddatek, który rozwija się niejako samoistnie, poza ekonomicznymi uwarunkowaniami:

Analizuję [...] źródło kształtowania się i przemian paryskich pasaży od samych ich początków aż do schyłku, uchwytując je poprzez fakty ekonomiczne. Ale fakty te, rozpatrywane pod kątem kauzalnym (a więc jako przyczyny) nie byłyby jednak prafenomenami; stają się nimi dopiero wówczas, gdy mocą własnej dynamiki rozwojowej (trafniej byłoby tu mówić o „odwijaniu się”) wyłaniają z siebie ciąg konkretnych, historycznych form pasaży, tak jak z liścia wyłania się stopniowo całe bogactwo empirycznego świata roślin?.

Dopiero wrażliwość na ten naddatek pozwala uchwycić „poetycką intensywność" procesu historycznego ${ }^{10}$, która wymyka się tradycyjnemu materializmowi. Zarazem Benjamin pokazuje, że kolektywne pragnienia i społeczne fantazje nie są ledwie mglistym eterem unoszącym się nad „twardą” bazą środków i stosunków produkcji. Wręcz przeciwnie - poprzez swoje materializacje zostają włączone w bazę, określając i wzmacniając jej charakter. Mit u Benjamina nie jest przeciwieństwem materii, ale jej nieodłącznym dopełnieniem - a metropolia stanowi ich modus vivendi. Całość miasta jest materialnym Zeit(t)raum („snoczasoprzestrzenią”). Osiami wyznaczającymi prawdziwą trójwymiarowość miasta są czas, przestrzeń i fantazja. Jednak powierzchnia miasta, po której przesuwa się oko patrzącego, najłatwiej pozoruje własną monolityczność i oskorupia się w mit. Podstawowym zadaniem dialektyka jest szukanie w niej pęknięć, by następnie zdecydowanym uderzeniem rozbić fałszywie spójny obraz. „Elementem ocalenia jest mocny, pozornie brutalny chwyt"11.

8 S. Buck-Morss, The Dialectics of Seeing..., s. 124.

9 W. Benjamin, Pasaże, s. 508 (N 2a, 4).

10 Zob. M. Berdet, What is Anthropological Materialism?, http://anthropologicalmaterialism.hypotheses.org/644

11 W. Benjamin, Pasaże, s. 522 (N 9a, 3). 


\section{Ruiny socjalistycznego Berlina}

Aby przy mocnym uderzeniu pięść nie zmiażdżyła własnego kciuka, kciuk prawidłowo zaciśniętej pięści pozostaje na zewnątrz, nigdy wewnątrz zwiniętej dłoni. Tak zwinięta w pozdrowieńczym geście bojowników Czerwonego Frontu, sama metalowa pięść Ernsta Thälmanna ma ponad metr wysokości. Popiersie przedwojennego niemieckiego komunisty ma czternaście metrów wysokości i piętnaście metrów szerokości. Odlany z brązu, ważący ponad pięćdziesiąt ton pomnik stoi w berlińskiej dzielnicy Prenzlauer Berg, na środku sporego, zupełnie pustego placu, na skraju osiedla-parku nazwanego imieniem Thälmanna. Thälmann ma za sobą komunistyczną flagę, a otacza go wieniec z drzew, zza których wystają symetrycznie rozstawione po obu stronach wieżowce $\mathrm{z}$ wielkiej płyty.

Osiedle-Park Ernsta Thälmanna, będące w 1986 roku jednym z najnowocześniejszych projektów mieszkaniowych, niemal natychmiast stało się reliktem przeszłości. Jako dzieło schyłkowe, po upadku muru pomnik Thälmanna nie budził tak wielkich emocji jak pomnik Lenina na Friedrichshain. Oczy wszystkich zwrócone były na nowe, tożsamościowe projekty: nowy plac Poczdamski czy przebudowę Reichstagu. Pomimo iż dzielnica Prenzlauer Berg była w centrum uwagi ze względu na kompleksowy projekt rewitalizacji (a de facto gentryfikacji), osiedle Thälmanna pozostawało na uboczu. Wielka płyta nie stanowiła atrakcyjnej konkurencji dla remontowanych przestronnych mieszkań starego budownictwa, dzięki czemu oparła się napływowi mieszczaństwa w stylu „Bionade-Biedermeier"12. Gigantyczne reflektory oświetlające niegdyś pomnik wyłączono. Pozbawiony władzy ideologicznej, pomnik stał się przede wszystkim materialnym obiektem. Oprócz wielkoformatowych graffiti nad kamiennym napisem Rote Front kolorowym sprayem nadpisane są zwykłe miejskie deklaracje miłości („Katja, I love you!”) i to, co tylko może przyjść do głowy, gdy letnim wieczorem, na rozgrzanym jeszcze od słońca, wygodnym cokole z ukraińskiego marmuru pije się piwo albo pali dżointa. „Na Thälmannie” jeździ się na deskorolkach, a czasami nawet celuje się w wielki nos z brązu kulką albo torebką z farbą. W dzień po pomniku buszują dzieci, a matki przysiadają, by na chwilę odpocząć. Thälmann na Prenzlauer Berg jest - na pierwszy rzut oka - pozostawiony samemu sobie. Chociaż w 1993 roku wydano oficjalne zarządzenie, by pomnik wysadzić w powietrze, nigdy tego nie zrobiono, gdyż na drogą eksplozję szkoda było pieniędzy z budżetu.

12 http://www.zeit.de/2007/46/D18-PrenzlauerBerg-46 


\section{Ekspolozja Jetzt-Zeit}

Kiedy w 1999 roku Związek Sił Demokratycznych Bułgarii (ZDS) za pomocą sześciusetkilogramowego ładunku po raz pierwszy próbował wysadzić w powietrze mauzoleum Dimitrowa w Sofii, w pobliskich budynkach rządowych popękały szyby, a centralny plac pokrył się grubą warstwą pyłu. Mauzoleum, zbrojone przeciwko atakom nuklearnym, pozostało nienaruszone. Podobnie przebiegały kolejne dwie próby, przy czym przy trzeciej ładunek zwiększono do dziewięciuset kilogramów. Plac wyglądał coraz gorzej, mauzoleum ledwie się przechyliło.

Wyjątkowo spektakularna porażka ZDS jest doskonałą lekcją Benjaminowskiej dialektyki mitu i materii. Wielki wybuch, który miał być manifestacją władzy ZDS i jej przewagi nad (pokonanym dziesięć lat

Moc, która zdolna

by była rozsadzić mit, można wydobyć jedynie z jego wnętrza.

Mit nie jest prostym zaprzeczeniem historii, ale przeciwnie - jej rdzeniem, w którym ukryta jest prawda o zbiorowości wcześniej) przeciwnikiem, nie tylko przywrócił całą symboliczną moc marmurowemu budynkowi (który od 1990 roku nie pełnił już funkcji mauzoleum i nie zawierał ciała Dimitrowa), ale jeszcze uzbroił go dodatkowo w 900 kg dynamitu, z manifestacji władzy czyniąc slapstickową komedię o nieudolnym despocie, w którego rolę niezamierzenie weszła ZDS. Komiczny charakter destrukcji nie wynikał przy tym wyłącznie z niekompetencji pirotechników, ale ze złego wyczucia czasu. Podupadła ideologia państwowego socjalizmu nie wymagała tak silnego uderzenia - więc jego siła obróciła się przeciwko ideologii uderzających (pięść zmiażdżyła swój własny kciuk). Moc, która zdolna by była rozsadzić mit, można wydobyć jedynie z jego wnętrza. Mit nie jest prostym zaprzeczeniem historii, ale przeciwnie - jej rdzeniem, w którym ukryta jest prawda o zbiorowości. Formy architektoniczne, pomniki, elementy miejskiego pejzażu jako sama fizjologiczna „wewnętrzność” zbiorowości „trwają w swej nieświadomej, nieukształtowanej formie snu, są czymś zupełnie takim samym jak procesy naturalne - trawienie, oddychanie [...] póki zbiorowość nie zawładnie nimi w polityce i póki nie narodzi się z nich historia"13. Kolektywne rozpoznanie mitu sprawia, że jego własną moc można wykorzystać do jego destrukcji. Stąd tak ogromną siłę wyzwalało burzenie pomników w stolicach byłego bloku wschodniego w 1989 roku.

W psychologii kolektywu mit pełni podobne funkcje, co sen w psychologii jednostki. Ponieważ jednak sen i jawa społeczeństwa są ze sobą dialektycznie splecione, do najważniejszych elementów dialektycznej metodologii należą techniki przebudzenia. Proces rujnacji jest powolnym procesem budzenia się. Dialektyczny kunszt nie polega jednak

13 W. Benjamin, Pasaże, s. 433 (K 1, 5). 
na tym, by w podlegającym rujnacji micie rozpoznać upadłe sny minionych pokoleń (by, jak w Sofii, dziesięć lat po upadku komunizmu rozpoznać w mauzoleum symbol komunistycznego ucisku), ale by w sposobie, w jaki dawne mitologie podlegają rujnacji, rozpoznać nadchodzący sen własnej epoki. To, co kiedyś wyrywało kolektyw ze snu, dziś samo może być elementem nowej mitologii, podczas gdy dawne formy mityczne wciągnięte w teraźniejszość mogą wyzwolić siły rozsadzające spójność onirycznej narracji. Nic nie jest progresywne albo reakcyjne jako takie.

Aby zniszczyć monolityczną strukturę, trzeba znaleźć lub spowodować w niej pęknięcie i rozsadzić ją od środka. Także tę benjaminowską lekcję rządowi pirotechnicy w Sofii przyswoili zbyt późno. Po sześciu dniach - tyle samo zajęło niegdyś zbudowanie pancernego mauzoleum - udało się zniszczyć budynek przy pomocy kilkunastu drobnych ładunków i buldożerów, które kruszyły popękane mury. Tymczasem odtwarzana jeszcze tysiące razy w Internecie seria nieudanych eksplozji zburzenia mauzoleum nieoczekiwanie ujawniła zupełnie inny mit - mit ciągłości, którą ZDS próbowała wytworzyć oraz mit „epoki upadku”, w którym nic, co pochodzące z komunistycznej przeszłości, nie mogło zostać ocalone. Największym grzechem ZDS okazał się całkowity brak poczucia teraźniejszości - niewrażliwość na Benjaminowski Jetzt-Zeit, który aktywuje energię pewnych wydarzeń historycznych, zamykając drogę do innych (bardziej mozolne akcje burzenia pomników w 1989 roku tylko wzmagały heroizm burzących). Dziesięć lat później, kiedy społeczeństwo bułgarskie już od dawna pozbawione było złudzeń nie tylko co do epoki komunizmu, ale i kapitalizmu, w przeprowadzonym sondażu 2/3 mieszkańców zagłosowało przeciwko wyburzeniu mauzoleum ${ }^{14}$.

Wszelka energia prowokująca polityczne przebudzenie jest kolektywną energią społeczną. Jej źródłem jest „byłość”, jej miejscem magazynowania - miasto, jej zapalnikiem - teraźniejszość: „, [materializm historyczny] [r] ozsadza ciągłość historii i wyrywa z niej epokę ze zreifikowanej »ciągłości historii«. Ale rozsadza również homogeniczność samej epoki. Napełnia ją ekrazytem, tj. teraźniejszością"15.

Teraźniejszość jest, według Benjamina, jedynym prawdziwym materiałem wybuchowym.

14 Cyt. za http://news.bbc.co.uk/2/hi/europe/431854.stm

15 W. Benjamin, Pasaże, s. 522 (N 9a, 6). 


\section{Obraz dialektyczny}

Moment nagłego poznania przyrównuje Benjamin do krótkiego spięcia - jakby patrzący na miasto patrzył zbyt intensywnie, tak że w tym „przeciążonym” patrzeniu powstaje zwarcie - dialektyczna iskra. Ładunkiem, który wytwarza się na chwilę w momencie takiego „przeciążenia” obwodów poznawczych, jest obraz dialektyczny. Dialektyczna iskra może wywołać kognitywną eksplozję, w której na ułamek sekundy normalny miejski proces dialektyczny zatrzymuje się niczym w klatce fotograficznej w momencie największego napięcia pomiędzy sprzecznościami (Benjamin nazywa to „zastygłą dialektyką” - Dialektik im Stillstand). Jetzt-zeit przestaje być zwykłym czasem teraźniejszym, stając się jego zagęszczeniem, czasem wielokrotnie teraźniejszym, w którym swoją teraźniejszość objawia zarówno potocznie ujęte „teraz” czasu fizykalnego, jak i uobecnione „teraz” byłości.

Obraz dialektyczny jest podstawowym pojęciem Benjamina, zarazem jednak jednym z najbardziej kłopotliwych. Przełożenie jego fenomenu na język metodologiczny przypomina bowiem próby instrumentalnego planowania (świeckich) iluminacji. Podstawowym problemem dla „niefilozoficznych", twardo stąpającyh po ziemi metodologów jest subiektywność. Spośród dwóch osób stojących obok siebie i patrzących w ten sam punkt, prawdopodobnie tylko jedna dozna owego „momentu spięcia”. Nawet ona nie może tego doświadczenia powtórzyć, a jedynie rekonstruować je za pomocą pamięci i pojęć. Jaką rolę w metodologii przypisać więc zjawisku, które pojawia się nie wiadomo skąd, na chwilę i nie dla wszystkich, i które zaraz znika? Wszystkie klasyczne problemy badań jakościowych tu radykalnie się wzmacniają: obrazy dialektyczne nie są intersubiektywne, są trudno operacjonalizowalne, niemal niemożliwe do zaplanowania i wreszcie, mimo najszczerszych chęci i rzetelnego przygotowania, całkiem zwyczajnie mogą nam się nie przydarzyć. Moment zatrzymania dialektyki jest bowiem dokładnie tym momentem, w którym Benjaminowski pozytywizm przeskakuje w magię.

Charakterystyczne, że pisząc tak wiele o obrazach dialektycznych, Benjamin nigdy nie opisuje szczegółowo żadnego konkretnego obrazu, który ukazał się jemu. Sygnały wskazujące u niego na przeżycie tego rodzaju są najczęściej zdawkowe i odnoszą się raczej do wskazania miejsca i momentu iluminującego szoku, niż do jego treści ${ }^{16}$. Nie wynika to ze słabości metodologicznej Benjamina, ale z niedyskursywnej i efemerycznej natury obrazów dialektycznych. Obraz dialektyczny należy do

16 Tamże, s. 117 (C 2a, 10). 
metodologii na bardzo szczególnych zasadach. Nie jest ani jej narzędziem (nie możemy powiedzieć, że badamy miasto za pomoca obrazów dialektycznych), ani jej celem (obraz nie jest nigdy tym, co ostatecznie poznajemy). Doświadczenie dialektycznego szoku jest raczej momentem „przełączenia pomiędzy porządkami ${ }^{17 ”}$, punktem kulminacyjnym badania, który zbieraninie fragmentów nadaje mocny impuls teleologiczny. Ponieważ źródłem obrazów dialektycznych jest monadyczna struktura fragmentów, dialektyczne spojrzenie stara się z jednej strony zebrać jak najwięcej fragmentów, z drugiej poprzez łączenie ich w różne konstelacje maksymalnie wyeksploatować ich potencjał.

\section{Techniki patrzenia}

Metodologia Benjamina jest metodologią nadmiaru. Nawet najskromniejsze próby jej zastosowania znakomicie wyjaśniają, dlaczego Pasaże nigdy nie mogły zostać ukończone. Benjamin jest systematycznym, pozytywistycznym archiwistą, który inwentaryzując nieskończoność miasta, jednocześnie raz po raz przemienia się w surrealistę-wizjonera: ze swoich fiszek, rycin i cytatów układa coraz to nowe montaże, by następnie porzucić je, zmotywowany nagłym pragnieniem odnalezienia brakującego elementu i dołączenia go do spisu. W swojej metodologii, podobnie jak w polityce Benjamin pozostaje wierny zasadzie, by działać „zawsze radykalnie, nigdy konsekwentnie ${ }^{18 ”}$. Jego eksperymenty myślowe, percepcyjne i analityczne można potraktować jako swoiste dialektyczne wprawki. Niektóre z tych ćwiczeń w patrzeniu, których w różnych miejscach można znaleźć u Benjamina co najmniej kilkanaście, rekonstruuję poniżej.

Technika (i) „antropocentrycznej topografii ${ }^{19 ”}$ opiera się na konstruowaniu topografii przestrzeni w oparciu o znaczenie jej poszczególnych elementów dla jednostek i dla kolektywu. $\mathrm{Na}$ tej zasadzie Benjamin proponuje (ii) budować alternatywne topografie w oparciu o pozornie nieistotne elementy (fontanny, burdele, dworce) lub (iii) „unerwiać” przestrzeń, architekturę i technologię perspektywą poszczególnych ludzkich doświadczeń, szukając zarazem (iv) ekspresyjnego nadmiaru, który wykracza poza funkcjonalną konieczność.

17 P. Osborne, Quasi-messianic Interruption, [w:] Walter Benjamin: Critical Evaluations in Cultural Theory, red. P. Osborne, t. 1, New York 2005, s. 324.

18 W. Benjamin, Gesammelte Briefe, Frankfurt 1997, s.425-426.

19 W. Benjamin, Pasaże, s. 115 (C2, 3).

W swojej metodologii, podobnie jak w polityce Benjamin pozostaje wierny zasadzie, by działać „zawsze radykalnie, nigdy konsekwentnie". Jego eksperymenty myślowe, percepcyjne i analityczne można potraktować jako swoiste dialektyczne wprawki 
Zabieg (v) zagęszczenia czasu ${ }^{20}$ polega na quasi-filmowym zagęszczeniu ruchu na danym placu lub w mieście, tak, by zmniejszyć dystans czasowy pomiędzy wydarzeniami i, w skrajnej wersji, stworzyć rodzaj (vi) montażu, w którym zjawiska $\mathrm{z}$ różnych porządków czasowych zostają zderzone w jednym porządku przestrzennym. Ten i inne rodzaje montażu należą zresztą do ulubionych technik Benjamina, inspirowanych przez surrealistów. Montaże ułatwić również mają znalezienie (vii) nieciągłości i pęknięć we wszelkich narracjach historycznych ${ }^{21}$. Za Brechtem Benjamin stara się spojrzeć na miasto jako na (viii) pole bitwy, wyodrębniając jak najwięcej konfliktów społecznych. Zabieg (ix) teleskopowania byłości ${ }^{22}$ jest rodzajem montażu, w którym wydarzenia z przeszłości zostają wprowadzone do teraźniejszości bez oceniającej, narracyjnej domieszki tego, co wydarzyło się w międzyczasie. Zarazem żadnego z tych ćwiczeń nie da się doprowadzić do końca, gdyż wymagałoby to wiedzy o całości miasta. Do tej Benjamin proponuje dotrzeć nie przez linearną konsekwencję, ale przez ciągłą zmianę perspektywy. Wypróbowując wybrane techniki Benjamina do analizy pomnika i osiedla Ernsta Thälmanna, postaram się pokazać, jak różne, często sprzeczne obrazy mogą się dzięki nim odsłonić.

\section{Antropocentryczna topografia}

Uznając topograficzny (i jako taki - materialny) aspekt miasta za kluczowy dla dotarcia do prawdy o jego całości ${ }^{23}$, Benjamin wprowadza do badań historyczno-topograficznych antropologiczną korektę, proponując „topografię inną, pomyślaną nie architektonicznie, lecz antropocentrycznie" ${ }^{24}$. Każdy element topograficzny miasta należy przebadać nie tylko ze względu na jego miejsce, formę i zależności pomiędzy nim i resztą elementów, ale także możliwie dokładnie przeanalizować jego różne znaczenia i wpływ na życie dla grup i jednostek. Taka topografia nie rozdziela pomiędzy miejscem w społecznych i indywidualnych historiach $^{25}$ a miejscem w przestrzeni. Przestrzeń zostaje „unerwiona” doświadczeniem.

20 Tamże, s. 112 (C 1, 9).

21 Tamże, s. $522(\mathrm{~N}$ 9a, 5).

22 Tamże, s.518 (N 7a, 3).

23 Tamże, s. 112 (C 1, 7).

24 Tamże, s.115 (C 2, 3).

25 Tamże, s.112 (C 1, 8). 


\section{Innerwacja}

W 1872 roku na łące, na której dzisiaj stoi osiedle-park Thälmanna, wybudowano gazownię. Mieszkańcy Prenzlauer Berg traktowali ją zarazem jako wybawienie i przekleństwo. $Z$ jednej strony państwowy pracodawca zapewniał stabilne zatrudnienie nawet w czasach kryzysu, z drugiej zakład radykalnie obniżał jakość życia, emitując wyziewy, kurz i sadzę ${ }^{26}$. Narzekano również na warunki pracy. W 1886 roku doprowadził w konsekwencji masowego strajku. Aktywnie rozwijający się ruch doprowadził w 1905 roku do skrócenia dnia pracy do ośmiu godzin. Radykalne zmniejszenie produkcji nastąpiło wraz z dojściem do władzy narodowych socjalistów. Węgiel był niezbędny do celów militarnych. Od strony Greifswalder Strasse, na miejscu dzisiejszego pomnika Thälmanna, powstała wysokociśnieniowa stacja paliwowa, w której gaz tankowały miejskie autobusy BVG (w ten sposób również benzynę oszczędzano na potrzeby zbrojeniowe ${ }^{27}$ ). Część robotników powołano do armii, a pod koniec lat trzydziestych podjęto decyzję o stopniowym przestawieniu miejskiego systemu na gaz ziemny, rozbiórce gazowni i wybudowaniu jej na terenie kompleksu sportowego z dużym basenem. Wybuch wojny unieważnił te plany, z których - aż do dzisiaj - pozostało jedynie boisko sportowe przy Winsstrasse.

Po wojnie władze NRD zdecydowały się zmodernizować gazownię, która działała nieprzerwanie aż do 1981 roku. Jak zauważa Soost ${ }^{28}$, efektywne zaopatrywanie miasta w gaz było w ogóle możliwe jedynie dzięki kreatywności i zaangażowaniu pracowników, którzy często musieli radzić sobie z brakiem surowców i części zamiennych, spowodowanym polityką gospodarczą NRD. Podjęta na X. Zjeździe Partii SED decyzja o zamknięciu gazowni i wybudowaniu na jej terenie osiedla-parku została przyjęta pozytywnie. Mieszkańcy wraz z zespołami z Uniwersytetu Humboldtów i Akademii Sztuk Pięknych w Weissensee aktywnie zaangażowali się w przygotowywanie planów przekształcenia na cele kulturalne trzech ogromnych gazomierzy, które miały być materialnym śladem robotniczej przeszłości dzielnicy. Niestety, wkrótce Erich Honecker odgórnie podjął decyzję o ich zburzeniu. Jako oficjalną przyczynę podano zanieczyszczenie gruntu. Jednak ze względu na pośpiech wywołany założoną datą otwarcia w stulecie urodzin Thälmanna, mimo wymiany gruntu pod zburzonym gazomierzem, pozostawiono w ziemi ogromne pojemniki

26 H. Soost, Gas und Koks, Ruß und Staub, „Berlinische Monatsschrift“ 2001, nr 4, s.52-53.

27 Tamże, s. 54.

28 Tamże, s. 59. 
ze smołą. Nad wyglądającym znakomicie na zdjęciach, luksusowym osiedlu mieszkaniowym na 1336 mieszkań i ponad 4000 mieszkańców, w którym od dnia otwarcia działały: dwa przedszkola, żłobek, dwa place zabaw, ozdobny staw z miniwodospadem, trzy sklepy, trzy restauracje, basen i planetarium, wkrótce zaczął unosić się nieznośny fetor. W wodach gruntowych jeszcze na początku lat dziewięćdziesiątych wykrywano cyjanki i fenole. Kontenery ze smołą w skomplikowany sposób usunięto, a oczyszczanie wód gruntowych trwa do dzisiaj.

Decyzja o zburzeniu gazomierzy wywołała masowe protesty. Mieszkańcy drukowali własne ulotki i naklejki z hasłem „Nie burzyć gazomierza!”. Wysyłano tysiące podań i oddolnie organizowano dyskusje o możliwych rozwiązaniach oraz o robotniczej historii dzielnicy. Erich Honecker zignorował wszystkie postulaty protestujących, przychylając się do opinii radzieckiego rzeźbiarza Lwa Kerbela, który miał powiedzieć, że gazomierze „optycznie przytłoczą” pomnik Thälmanna. Teren gazomierza ogrodzono, fotografów wyproszono. Ostatnią noc przed wysadzeniem spędziło w gazomierzu kilkunastu pracowników Stasi, pilnując, by nie doszło do blokady ze strony strajkujących. Thomas Frierl, jeden z aktywnie protestujących członków SED, za swój udział w proteście utracił asystenturę na Uniwerystecie Humboldtów. Na uroczystości otwarcia osiedla i odsłonięcia pomnika 15 kwietnia 1986 Erich Honecker przemawiał z dumą: „Nic nie będzie już przypominać o tym, co tu kiedyś było, nic o smrodzie, o złych warunkach życia i pracy, nic o napadach Schupo i bojówek SA, które wielu proletariuszy kosztowały życie. Dzisiaj to proletariusze są panami tego miasta, miasta pokoju, stolicy NRD, Berlina"29. Po przemówieniu kilkuletnia pionierka zaśpiewała piosenkę „Mały biały gołąbek pokoju”.

Projekt pomnika autorstwa Kerbela mieszkańcy uznali za zbyt agresywny. Po jego opublikowaniu w 1982 roku wybuchła fala protestów. Artyści byli rozżaleni tym, że nie zorganizowano otwartego konkursu. Szczególnie tragiczną postacią w tym kontekście jest rzeźbiarka Ruthild Hahne, której zaprojektowanie pomnika Thälmanna (w innym miejscu) zaproponowano w wyniku ogłoszonego konkursu już w 1950 roku. Przez piętnaście lat Hahne pracowała nad kolejnymi wersjami pomnika, raz po raz odrzucanymi do poprawek, tracąc kolejnych sojuszników i w efekcie rujnując swoją karierę. Sprowadzony ze Związku Radzieckiego Kerbel traktowany był tymczasem $\mathrm{z}$ atencją $\mathrm{i}$ - jak zauważali złośliwi - służalczością, odzwierciedlającą ówczesną politykę NRD. Pomnik

29 Cyt. za Monteath, P. (red.). Ernst Thalmann. Mensch und Mythos, Amsterdam 2000, s.191 
Thälmanna zamazywał indywidualność bohatera, uniwersalizując go jako symbol władzy. Thälmanna z Prenzlauer Berg nazywano „Lehmannem” (ze względu na wyraźnie przypominającą Lenina fizjonomię) lub po prostu "gigantyczną przypinką do klapy marynarki”. Do Ericha Honeckera napisała nawet kobieta, która znała Thälmanna osobiście z czasów powstania w Hamburgu, skarżąc się, że projekt nie ma nic wspólnego z „naszym Teddym”, który „zawsze miał kontakt z ludźmi i nigdy nie oddzieliłby się od nich tak jak na tym modelu, na którym patrzy do góry" ${ }^{30}$. Jednocześnie pomnik stał się centralnym punktem typowej dla NRD symbolicznej choreografii władzy, w którą wplatały się indywidualne historie: mianowania na pioniera, pasowania na żołnierza, obchody i festyny.

Po upadku NRD utworzona została specjalna komisja, która decydowała o losach socjalistycznych pomników. W 1992 roku podjęto oficjalną decyzję o wysadzeniu Thälmanna w powietrze. Thomas Frierl, ten sam, który będąc jeszcze w SED, bronił gazowni, mówił teraz, że pomnik jest symbolem „głęboko niedemokratycznych związków pomiędzy polityką, sztuką i sferą publiczną" ${ }^{31}$. Mieszkańcy znów protestowali, jednak Thälmann wygrał początkowo nie dzięki sile społecznego protestu, ale dzięki sile swojej monumentalnej materii, wplecionej, mówiąc językiem Marksa, w ekonomiczne zależności bazy. Podjętą przez komisję decyzję o zburzeniu pomnika przekazano do władz dzielnicy, które stwierdziły, że na drogą operację zburzenia ważącego 50 ton Thälmanna nie ma w budżecie pieniędzy. Pomnik pozostał, stając się czysto materialnym elementem lokalnej topografii, na który projektowano różnego typu konflikty.

\section{Pole walki}

„Miasta są polami walki” - stwierdza Benjamin, recenzując Czytanki dla mieszkańców miast Brechta. Brecht fascynuje Benjamina jako anty-flaneur, który nie daje się ponieść estetycznej fascynacji, zachowując strategiczną czujność na konflikt społeczny. „Trudno wyobrazić sobie obserwatora bardziej nieczułego na uroki krajobrazu niż ten, który został strategicznie wyszkolony w czasie bitwy"32. Niewrażliwy na wielkomiejskie przebodźcowanie, obojętny na detale architektoniczne, Brecht jest wyczulony

30 Tamże, s. 193.

31 P. Saunders, The Ghosts of Lenin, Thalmann and Marx in the Post-Socialist Cityscape, "German Life and Letters" 2010, nr 63, s. 450.

32 W. Benjamin, Gesammelte Schriften, Frankfurt 1991, s. 556.

Thälmann wygrał początkowo nie dzięki sile społecznego protestu, ale dzięki sile swojej monumentalnej materii, wplecionej, mówiąc językiem Marksa, w ekonomiczne zależności bazy 
na najsubtelniejsze zachowania mieszczan. Obaj z Benjaminem w najbardziej spójnym miejskim krajobrazie próbują dostrzec symptomy toczącej się walki oraz „punkty, w których tradycja się rwie, a zatem jej chropowatości i zadziory umożliwiające chwyt temu, kto pragnie wspiąć się ponad nią" ${ }^{33}$.

\section{Powierzchnia}

W jednym z projektów rewitalizacji pomnika Thälmann miał zostać obsadzony rosyjską winoroślą, w innych pneumatyczny podnośnik umożliwiłby spojrzenie Thälmannowi prosto $\mathrm{w}$ metalowe oczy, otoczenie go labiryntem lub przerobienie na fontannę $e^{34}$. Na rewitalizację jednak, podobnie jak na zburzenie, w intensywnie gentryfikowanej dzielnicy Prenzlauer Berg nie starczyło środków. Niewielki targ z produktami regionalnymi, który początkowo działał wokół pomnika, nie utrzymał

Zideologicznej

figury Thälmann stał się nagle gładka, płaską powierzchnia horyzontalną, na której można (w dzień w cieniu rzucanym przez wielką brązową głowę, nocą na długo utrzymującym

ciepło granitowym postumencie) odpocząć, oprzeć się, wypić piwo i porozmawiać

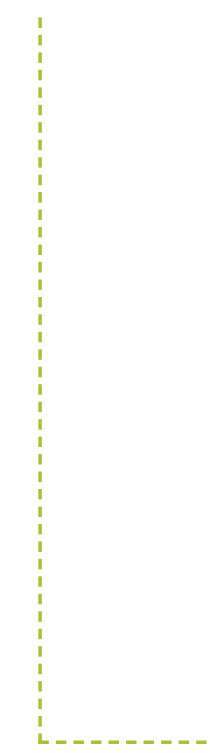
się. Po dewaluacji wymiaru symbolicznego, monumentalna materialność pomnika stała się jego dominującą wartością. Z ideologicznej figury Thälmann stał się nagle gładką, płaską powierzchnią horyzontalną, na której można (w dzień w cieniu rzucanym przez wielką brązową głowę, nocą na długo utrzymującym ciepło granitowym postumencie) odpoczą́, oprzeć się, wypić piwo i porozmawiać. Thälmann był gładką, płaską powierzchnią wertykalną znakomicie nadającą się na graffiti. Niewielki placyk okazał się ciągiem stopni o różnej wysokości, na których można ćwiczyć skoki na deskorolce, a wielka głowa - celem, do którego znakomicie jest rzucać szyszkami albo strzelać kulkami z farbą. Cały pomnik stał się ponadto obiektem alternatywnej turystyki, lokalnym kuriozum, które napływająca na Prenzlauer Berg nowa klasa średnia mogła od czasu do czasu pokazywać znajomym.

O tym, że spór ideologiczny nie ustał, świadczyły agresywne wypowiedzi niektórych polityków, jak i nieoczekiwana kontrofensywa obrońców Thälmanna. Na pomniku pojawił się nadmalowany nad graffiti napis „Eingekerkert, ermordet, beschmiert” („osadzony, zamordowany, zabazgrany"), odwołujący się bezpośrednio do historycznej postaci Ernsta Thälmanna. Pochodzący ze Stuttgartu (a zatem nieobciążony wspomnieniem ideologii NRD) student Max Renkl razem z grupą młodych antyfaszystów oraz starych „towarzyszy” z SED, wspomagany przez protestujących przed laty przeciwko zburzeniu pomnika mieszkańców osiedla założył w 2000 roku Thälmann-Aktionsbündnis (TA - Sojusz Działaczy Thälmanna): organizację, której główną motywacją był sprze-

33 Tamże, Pasaże, s. 522 (N 9a, 5).

34 „Berliner Zeitung”, 3 lipca 1996. 
ciw wobec bazgrania po pomniku. Stan, w jakim znajdował się pomnik wedle działaczy TA, nie licował z bohaterskim życiorysem przedwojennego lewicowca.

We wrześniu 2001 roku około dwudziestu wolontariuszy z TA w wieku od 18 do 75 lat przez cały tydzień, osiem godzin dziennie, samodzielnie czyściło ogromny pomnik przy pomocy acetonu, drucianych szczotek i palników gazowych. Jednocześnie rozdawano ulotki dotyczące historii Thälmanna. Już w kilka tygodni po pierwszej akcji sprzątającej pomnik był ponownie zabazgrany. Z początku członkowie TA starali się regularnie usuwać pojawiające się napisy, organizując akcje czyszczące co kilka tygodni. Powierzchnia pomnika na zmianę była zabazgrana i czysta. Pomiędzy „zwykłymi” napisami sporadycznie pojawiały się na pomniku również swastyki i symbole nazistowskie. W 2004 roku doszło do zorganizowanego ,ataku” nazistów. Na oczyszczonym pomniku namalowano swastyki i trupie czaszki, które policja zamalowała farbą dyspersyjną, wyjątkowo trudną do domycia dla działaczy TA. Ze względu na swastyki oraz naciski ze strony TA, w 2007 roku miasto podjęło decyzję o wynajęciu firmy sprzątającej, która myje pomnik dwa razy w roku w dzień urodzin i rocznicę śmierci Thälmanna. Na swoich ulotkach wizerunek pomnika zaczął wykorzystywać lokalny oddział międzynarodowej organizacji antyfaszystowskiej Antifa. Propozycje TA, by wynająć ochroniarzy pilnujących pomnika zostały odrzucone, TA nie udaje się też znaleźć sponsora, który opłaciłby włączanie nocą ogromnych stadionowych reflektorów oświetlających komunistycznego bohatera w zamian za możliwość umieszczenia na tych reflektorach reklam.

Obecnie przez większą część roku pomnik jest zabazgrany, zmieniają się tylko napisy. Dwa razy w roku, w każdą pierwszą sobotę po urodzinach/rocznicy śmierci Thälmanna działacze TA organizują uroczystości: zbierają się pod pomnikiem, składają kwiaty, rozstawiają czerwone flagi, czytają stare przemówienia Thälmanna i krytykują współczesny kapitalizm. Choć skład Thälmann Aktionsbündnis jest - poza ogólną deklaracją lewicowości - ideowo dość różnorodny, podczas festynu, który udało mi się obserwować 20 sierpnia 2010 roku najbardziej widoczna była opcja postenerdowska. Śpiewano piosenki o Thälmannie, odczytywano jego przemówienia, także te, które kończą się słowami „Lenin to partia, partia to Lenin”. Kiedy odjeżdża półciężarówka, z której sprzedawany jest chleb ze smalcem i ogórki kiszone, pomnik znów z miejsca festynu staje się nieco opustoszałym, wygodnym i intymnym miejscem spotkań. „Spotkałem się przy pomniku z kilkoma przyjaciółmi, by napić się piwa i przyjemnie zakończyć pogodny, piątkowy wieczór” - rozpo- 


\section{Sprawa Thälmanna,}

a konkretnie pytanie,

czy środowiska, które

definiują się jako

lewicowe powinny malować po pomnikach lewicowych bohaterów,

stała się przyczyną

kolejnej odsłony

konfliktu pomiędzy

berlińskim street artem

i sceną graffiti czyna swoją notkę internetową blogger Ghost Dog ${ }^{35}$. Wieńce dla Thälmanna więdną, postument znów pokrywa się napisami, jak ten, dopisany ostatnio kredą: „Arndt, jesteś przygodą mojego życia”.

\section{Konflikt}

„Ziomal Thälmann jest najnowszym członkiem DKM, poza tym to zajebista miejscówka" ${ }^{36}$ - pisze na forum ElBrÖ. DKM to berlińska ekipa grafficiarzy, która kilkakrotnie na miejsce bombingu wybierała pomnik Thälmanna. Sprawa Thälmanna, a konkretnie pytanie, czy środowiska, które definiują się jako lewicowe powinny malować po pomnikach lewicowych bohaterów, stała się przyczyną kolejnej odsłony konfliktu pomiędzy berlińskim street artem i sceną graffiti. Wpisane przez Thälmann Aktionsbündnis do programu hasło „Zjednoczeni przeciwko prawicy" okazało się w tym przypadku pobożnym życzeniem. Chociaż sami działacze TA od początku podkreślali, że nie są przeciwko graffiti, chcą jedynie chronić pamięć o Thälmannie, dyskusje na forum pełne są agresji pomiędzy środowiskami, dla której pomnik stanowi naturalny katalizator, pretekst, by odnowić dawne konflikty. Jedni mówią o „pohańbieniu pomnika” podobnym do działań neofaszystów i o pozorowanej lewicowości, inni powołują się na tradycję grafficiarzy i samą formę pomnika. Jak pisze członek DKM:

\footnotetext{
Po pierwsze nie robimy street artu jak te dzieciaki, które myślą, że mają coś wspólnego z graffiti. Naszą dewizą jest bombing aż do bólu zębów i gówno mnie obchodzi jakiś stalinistyczny pomnik. Nawet jeśli ziom Thälmann miał parę dobrych pomysłów, nie malowaliśmy po gębie tylko po postumencie. Poza tym grafficiarze zawsze walczą o fejm, wykorzystując wolne miejsca, a nie próbują jakimiś drukowanymi naklejkami „upiększać miasto” [...]. Prawo jest wszystkim, street art niczym ${ }^{37}$.
}

Pomiędzy moralistyką a prowokacją pojawiają się pojedyncze głosy łagodzące, w których powraca krytyka formy pomnika: ,ale co to właściwie ma za znaczenie, kim jest ten monstrualny koleś?"’38. DKM i inne ekipy dalej bombardują.

35 http://ghostdog19.wordpress.com/2007/04/14/eine-nacht-bei-ernst-thalmann/

36 Cała dyskusja tu: http://lilapapierschwein.blogsport.de/2007/08/02/1944ermordet-seit-dem-immer-wieder-geschaendet-rotfront/

37 Tamże.

38 Tamże. 


\section{Zagęszczenie czasu/montaż}

Część technik poznawczych Benjamina polega na (percepcyjnych) manipulacjach czasem - zaburzaniu zwykłego, chronologicznego porządku czasowego przez np. przyspieszanie go tak, by cała różnorodność wydarzeń stała się przestrzennie i poznawczo bliska lub wręcz jednoczesna. Ważny jest przy tym wizualny (filmowy, choreograficzny) wymiar takiej percepcji. Film dla Benjamina to medium, które „dialektyzuje” percepcję patrzącego:

Czy na podstawie planu Paryża nie dałoby się nakręcić pasjonującego filmu? Odsłaniając w kolejności chronologicznej rozmaite jego oblicza? Zagęszczając do pół godziny ruch przez całe stulecie pulsujący na ulicach, bulwarach, w pasażach i na placach ${ }^{39}$ ?

Badacz-dialektyk może dostrajać swoją percepcję jeszcze dalej, poza ograniczenia taśmy filmowej. Nakładając na siebie wszystkie klatki filmu, tworzy rodzaj montażu, w którym zestawia w jednej przestrzeni elementy należące do niej w różnych porządkach czasowych, eksperymentując z ich połączeniami i wypróbowując najbardziej absurdalne połączenia. Benjamin antycypuje i radykalizuje proponowaną później dla antropologii przez Clifforda Geertza technikę „gęstego opisu”. Materialista antropologiczny w swoim opisie zagęszcza nie tylko elementy z teraźniejszości, ale i z przeszłości, zestawiając to, co pozornie nie ma ze sobą nic wspólnego. Prostokątny kawałek przestrzeni pomiędzy Greifswalder Strasse, Danziger Strasse, Ella-Kay-Strasse i torami S-Bahnu w zagęszczonej, filmowej perspektywie ukazuje sceny bardzo poważne i zupełnie surrealistyczne.

\section{Choreografia strajku}

Grupa nastolatków pali jointa na stacji benzynowej, na środku której stoi pomnik Ernsta Thälmanna. Pod postument podjeżdżają tankować autobusy BVG. Z lewej strony nadchodzi grupa strajkujących robotników, domagających się skrócenia dnia pracy. Dołączają do nich mieszkańcy Prenzlauer Berg, spontanicznie organizując przy dystrybutorze gazu napędowego dyskusję o robotniczej przeszłości dzielnicy. Rozrzucają ulotki, skandując „Nie burzy się gazomierza”. Ktoś otwiera piwo, ktoś inny pisze sprayem na Thälmannie: „Nie burzy się gazomierza”. Tymczasem grupa wschodnioniemieckich artystów oprotestowuje monumentalność stojącego nad nimi pomnika, którego gigantyczna pięść

39 W. Benjamin, Pasaże, s. 112 (C 1, 9). 
wzniesiona jest w tym samym geście, co pięści strajkujących nieopodal pracowników gazowni. Ruthild Hahne proponuje, by zamiast popiersia postawiono równie wielką postać maszerującego z uniesioną pięścią Thälmanna, za którym poszliby robotnicy. Z wielkopłytowych wieżowców wychodzą mieszkańcy, protestując przeciwko wyburzeniu pomnika, mieszając się z kolorowym korowodem Antify. Krzyki robotników, mieszkańców, artystów, antyfaszystów nakładają się w jeden głośny, niespójny krzyk. Na środku stacji benzynowej, tuż przy dystrybutorze dziewczynka-pionierka w białej koszulce pobrudzonej sadzą śpiewa piosenkę „Mały biały gołąbek pokoju”.

\section{Choreografia oczyszczania}

Powietrze pachnie sadzą, smołą i węglem. Rozlega się wybuch. W powietrzu unosi się pył i gruz z wyburzonej gazowni. Powietrze stopniowo się oczyszcza. Mieszkańcy oddychają z ulgą, podczas gdy w wodach gruntowych specjaliści odkrywają cyjanki i fenole. Pod dawnym gazomierzem

Wszystkie techniki patrzenia Benjamina służą w gruncie rzeczy jednemu celowi: aby „[u]bijać sobie mózg jak masło, aby dobyć zeń zadziwienie"

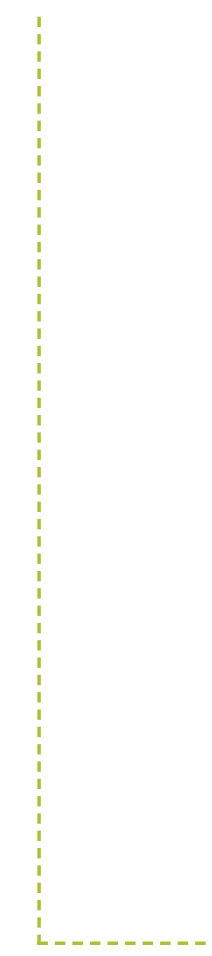
zakopane są pojemniki ze smołą. Powietrze zaczyna nieprzyjemnie pachnieć. Podziemne pompy oczyszczają wody gruntowe. Smoła zostaje wykopana. Powietrze się oczyszcza. Grafficiarze brudzą pomnik. Środek czyszczący Chemistrip, zakupiony przez działaczy TA okazuje się toksyczny. TA myje pomnik przy pomocy acetonu i palników gazowych. W barze „Pod latarnią gazową”, w Parku Thälmanna nagle zaczyna pachnieć gazem. Grafficiarze brudzą pomnik. Pompa pompuje wody gruntowe. TA myje pomnik. Streetartowcy brudzą pomnik. TA myje pomnik. Grafficiarze brudzą pomnik. TA myje pomnik. Graficiarze brudzą pomnik wielkimi literami z nazwą swojej grupy. Nastolatek brudzi pomnik wyznaniem miłosnym. Neonaziści brudzą pomnik swastykami. Honecker przemawia pod pomnikiem. Neonaziści brudzą Honeckera swastykami. Policja zamalowuje swastyki specjalną farbą. TA ma problemy z domyciem farby dyspersyjnej, której używa policja. Wynajęta przez miasto prywatna firma sprzątająca myje Honeckera. TA próbuje przekonać reklamodawców, by włączyli reflektory. Pomnik jest dalej zabazgrany. Graffiti na pomniku zmienia się niczym w kalejdoskopie. TA przez wiele godzin szczotkami szoruje pomnik, który nagle, zamiast graffiti, pokryty jest sadzą.

\section{Pozytywistyczny mesjanizm}

Wszystkie techniki patrzenia Benjamina służą w gruncie rzeczy jednemu celowi: aby „[u]bijać sobie mózg jak masło, aby dobyć zeń zadziwienie ${ }^{40}$ ”. $\mathrm{Ci}$, którzy od metody Benjamina natychmiast oczekują naukowych wnio-

40 Tamże, s. $326(\mathrm{~J} 37,2)$. 
sków, z pewnością będą zawiedzeni. Jak pisze Berdet, metoda Benjamina jest raczej „wrażliwością, która uchwytuje grę i stawanie się w akcji”, oferując „metonimię dla jądra historyczności, którego nie można wyrazić za pomocą symbolu, nie tracąc jego specyfiki ${ }^{41}$. Im odważniej budujemy surrealistyczne montaże, tym bardziej „naukowa przytulność” się rozpada. Niejednoznaczne i niespójne okazuje się w zasadzie wszystko: historyczna postać Thälmanna, sposób wykorzystania tej postaci przez propagandę NRD, historia robotników i mieszkańców Prenzlauer Berg, projekt Ruthild Hahne i sposób jego odrzucenia przez władze NRD, projekt Lwa Kerbela, konflikt o wyburzenie pomnika, stanowiska poszczególnych partii politycznych, działania Thälmann Aktionsbündnis, wewnętrzne podziały środowisk definiujących się jako lewicowe. Każdą z wytworzonych narracji można dość szybko rozbić inną. Zestawiając je razem, nie sposób utrzymać narracyjnej spójności.

Będąc upadłą fantasmagorią władzy, jako ruina pomnik Thälmanna okazuje się być miejscem ściśle antyfantasmagorycznym. Jeśli fantasmagoria jest „fałszywą syntezą wszystkich społecznych sprzeczności” oraz „fałszywą syntezą przeszłości i przyszłości”ł2 , pomnik Thälmanna - utrzymując dynamikę konfliktu bezpośrednio na swojej materialnej powierzchni - nie dopuszcza do trwałego ugruntowania się żadnej tego typu syntezy. Podczas gdy władze miasta proponują coraz to nowe reprezentacje nowoczesności i postępu zjednoczonego Berlina, Thälmann ze swoimi cyklami czyszczenia i brudzenia okazuje się błędem systemu, zdartą płytą. Powierzchnia pomnika lepiej niż wyrafinowane projekty sztuki krytycznej rozsadza ideologiczne narracje. A ponieważ materialne stany Thälmanna (czysty/brudny) przechodzą jeden w drugi, interpretacja nigdy nie może być domknięta. Nieoczekiwanie jednak, oprócz narracji o zjednoczeniu i postępie Thälmann rozsadza też inną - o jedności berlińskiej lewicy. Nawet lewicowa historia jest zawsze „pisana przez zwycięzców”, nawet jeśli zwycięstwo oznacza tyle co uporczywość materii. Niezależnie od kontrowersji ideologicznych wokół postaci oraz pomnika Thälmanna, ich obecność w lokalnych dyskursach pamięci jest o wiele wyraźniejsza niż postacie robotników strajkujących w gazowni, która wraz z wysadzeniem gazomierza w zasadzie zniknęła z publicznego dyskursu.

Powierzchnia pomnika prezentuje nie tyle zatrzymanie, co zapętlenie procesu dialektycznego. Jeśli obraz dialektyczny jest subiektywnie zapo-

41 M. Berdet, Seven Short Temporary Statements on Anthropological Materialism, http://anthropologicalmaterialism.hypotheses.org/822

42 Tegoż, Eight Thesis on Phantasmagoria, http://anthropologicalmaterialism. hypotheses.org/611 
średniczonym zatrzymaniem tego procesu, dialektyczna pętla jest raczej wewnętrznym błędem systemu, który uniemożliwia zbyt szybkie przejście do Aufhebung i zmusza do powrotu do punktu wyjścia. Dzięki temu wewnętrzne sprzeczności systemu raz po raz wypływają na powierzchnię, zwiększając możliwość kolizji byłości z teraz-czasem i powstawania obrazów dialektycznych. Swoisty replay testuje dialektyczne możliwości coraz to nowych teraz-czasów.

W swojej metodologii Benjamin wskazuje zarówno na niezbędność pozytywizmu, jak i na konieczność jego przekroczenia. Jego główną metodologiczną sztuczką jest uchwytywanie więcej niż w zasadzie da się uchwycić. Ciągłe zmiany perspektywy, w których miasto odsłania swoją „porowatość” ${ }^{3}$ i niekompletność każdego z wymiarów: materialnego, społeczno-politycznego i fantasmagorycznego. W przeciwieństwie do klasycznych metodologii, Benjamin nie ucieka od tej porowatości, ale wykorzystuje jej potencjał, próbując dotrzeć do całości przez monadyczny fragment. Nie boi się przy tym zanieczyścić rzeczywistości mitem, przekonany, że mity są pełnoprawnymi częściami miejskiej całości. Benjamin koncentruje się przede wszystkim na momencie przenikania się wymiaru materialnego i społecznego, rzeczywistości i fantazji, mitu i jego rujnacji. Jeśli nie możemy uchwycić całości miasta jako statycznego bytu, możemy uchwycić ją w dynamicznym przekroju teraz-czasu. Całość nie jest przy tym linearna, jest uchwytywana nie z perspektywy ale ze środka teraz-czasu.

Dialektyczne techniki badawcze nie oferują łatwego przejścia do „wyników badań”. „W dziedzinach, jakie tu roztrząsamy, poznanie to jedynie piorunowy błysk. Tekst to dudniący długo potem grzmot" ${ }^{\text {"44 }}$. Metodologia Benjamina jest metodologia patrzenia, a nie metodologią pisania raportów badawczych. To, co staje się dzięki niej widoczne, to „określony punkt krytyczny” wewnętrznej dynamiki miasta jako całości, zapośredniczonej poprzez obraz dialektyczny ${ }^{45}$. Z punktu widzenia praktyki produkcji wiedzy, negatywny, destrukcyjny aspekt metodologii Benjamina jest dużo łatwiejszy do uchwycenia, podczas gdy jej aspekt pozytywny gubi się w linearności „zwykłych” tekstów naukowych. Prawdziwym wyzwaniem byłoby więc przekroczenie tej sprzeczności: stworzenie modelu naukowości, który nie implikowałby koniecznie linearnego modelu spójności, tak odległego od dialektycznej nieskończoności realnego miasta.

43 Benjamin rozwinął koncept „porowatości” miast wraz z Asją Lacis.

44 W. Benjamin, Pasaże, s. 502 (N 1, 1).

45 Tamże, s. 509 (N 3, 1). 
Dzieło Benjamina otwiera polityczno-mesjanistyczną perspektywę na miasto. $Z$ napięcia pomiędzy niekompletnością ruiny i przebłyskiem obrazu dialektycznego rodzi się impuls politycznego działania skierowanego i na przeszłość, i na przyszłość (a także na przyszłość każdej przeszłości). Tu jeszcze raz magia zderza się z pozytywizmem: „magiczny” moment rewolucji powinien być uzupełniony pozytywistycznym zadaniem zbawienia. Świecka energia takiego mesjanistycznego pozytywizmu pochodzi z siły „słabego mesjanizmu”, o którym Benjamin wspomina w Tezach o pojęciu historii, a który oparty jest na regulatywnej idei szczęścia jako ziemskiego (słabego) odpowiednika zbawienia. Miasto wyładowane jest przeszłymi nadziejami i oczekiwaniem szczęścia przeszłych generacji. Rewolucyjny potencjał tych nadziei jest przechowywany w miejskiej materii. Strajk robotników gazowni i duma młodego pioniera uhonorowanego pod pomnikiem Thälmanna, nadzieja na lepsze warunki życia w zanieczyszczonej dzielnicy, zawiedzione nadzieje artystki Ruthild Hahne, fejm ekip graficiarskich i wspomnienia pocałunków na pomniku - wszystkie te wydarzenia powinny nie tylko przejść proces krytycznej destrukcji ich ideologicznych kontekstów, ale też pozytywnej archeologii ich rewolucyjnego potencjału. Zadaniem dialektyka jest uwolnienie ich z ruin, ocalenie ich strony pozytywnej i włączenie ich energii w porządek miejskiej codzienności. Jest to zadanie pozytywistyczne, przypominające mozolne oddzielanie grochu od popiołu z bajki o Kopciuszku:

Skromna propozycja metodologiczna odnośnie do dialektyki dziejów kultury. Bardzo łatwo jest dla każdej epoki, na rozmaitych „polach”, dokonać dychotomicznych podziałów, kierując się określonym punktem widzenia. W taki sposób z jednej strony mamy wszystko to, co „płodne”, „obiecujące”, „żywotne”, „pozytywne”, z drugiej zaś znajdują się aspekty jałowe, zacofane i martwe danej epoki. Tylko po nakreśleniu zarysów tej części pozytywnej na tle negatywnej uzyskujemy wyraźny jej profil. $\mathrm{Z}$ drugiej strony każda negacja ma wartość tylko jako tło dla konturów tego, co żywotne i pozytywne. Stąd jest niesłychanie ważne, by tę część negatywną, już wcześniej wydzieloną, znów poddać podziałowi, tak by przy zmianie kąta widzenia (ale nie miary) ponownie objawiła ona stronę pozytywną, różną od tej wskazanej wcześniej. I tak dalej, in infinitum, aż cała przeszłość drogą historycznej apokatastazy ulegnie włączeniu w teraźniejszość ${ }^{46}$.

Poza szaleństwem owego in infinitum badaczkom-benjaministkom pozostaje jedynie mozolne krzesanie dialektycznych iskier.

46 Tamże, s. 505 (N 1a, 3). 
JOANNA KUSIAK (1985) - studiowała filozofię i socjologię na Uniwersytecie Warszawskim (MISH) oraz Uniwersytecie Humboldtów w Berlinie. W swoich badaniach nad miastem łączy badania empiryczne z wątkami filozoficznymi oraz krytyką ideologii. Obecnie pracuje nad książką-doktoratem o transformacji Warszawy i pojęciu „chaosu” w studiach miejskich. Doktorantka na Uniwersytecie Warszawskim i Darmstadt University of Technology, w latach 2011/2012 Fulbright Visiting Scholar na City University of New York. Wraz z Moniką Grubbauer opublikowała tom "Chasing Warsaw: Socio-Material Dynamics of Urban Change after 1990" (Chicago 2012). Laureatka nagrody START Fundacji Nauki Polskiej.

\section{Dane adresowe:}

The Graduate Center

3655 th Ave

New York

United States 10016

e-mail: jkkusiak@gmail.com

\section{Cytowanie}

J. Kusiak, Walter Benjamin i metodologia antropologicznego materializmu. Krzesanie dialektycznych iskier na metalowej gtowie Ernsta Thälmanna, „Praktyka Teoretyczna” nr 2(8)/2013, http://www.praktykateoretyczna. pl/PT_nr8_2013_Teologie_emancypacyjne/14.Kusiak.pdf (dostęp dzień miesiąc rok)

Author: Joanna Kusiak

Title: Walter Benjamin and the Methodology of Anthropological Materialism: Striking Dialectical Sparks from Ernst Thälmann's Bronze Head

Abstract: In his methodology as well as his political thought Benjamin remains faithful to the principle to proceed "always radically, never consistently". Therefore, the greatest challenge for a contemporary city researcher inspired by Benjamin is to operationalise his materialist methodology. Benjamin's anthropological materialism cannot be reached within the fixed limits of any discipline, but rather places itself "on the crossroads of magic and positivism" (Adorno); the dialectical image is not a tool of his methodology but its culminating point where positivism turns to magic. To reach this point, Benjamin conducts perceptive and analytical experiments that can be treated as dialectical études, exercises in seeing. The paper examines some of these techniques, exploring their philosophical context and testing them on a contemporary example: the Ernst-Thälmann-Monument in Berlin.

Keywords: Walter Benjamin, anthropological materialism, dialectics, dialectical image, city, collective memory, messianism 